\title{
Subsidiarity to the Rescue for the European Courts? Resolving tensions between the Margin of Appreciation and Human Rights Protection
}

\begin{abstract}
The empty phrases concerning the states' margin of appreciation - repeated in the court's judgments for too long already -are unnecessary circumlocutions, serving only to indicate abstrusely that the States may do anything the Court does not consider incompatible with human rights
\end{abstract}

(Brauch 2005, 148)

One of the constant tensions in multilevel legal and political orders concerns the allocation of authority among the bodies at different levels. ${ }^{1}$ What scope of autonomy should they enjoy over various issue areas, and how should they be checked or balanced? One of the recent arenas for such tension and debate concerns the role of the European Court of Human Rights (ECtHR), which is entrusted the power of judicial review over the member states of the Council of Europe's compliance with the European Convention on Human Rights (ECHR, Convention). According to the 'Copenhagen Criteria' of accession to the EU, the ECtHR thus serves important gate keeper functions for applicant states to the European Union (European Council 1993). It also monitors the continual compliance with the Convention by existing members - which is of shared concern for all EU states. In exercising its powers, the Court must often combine apparently irreconcilable requirements: it must assess and sometimes criticize the states' legislation and policies - yet respect the sovereignty of those of the states which are well functioning democracies. Further controversies have been fuelled by the EU member states' decision that the EU itself shall accede to the ECHR (European Council 2007, Art 6.2), especially by the Court of Justice of the European Union's (CJEU) rejection of the draft accession treaty (CJEU 2014). The CJEU was inter alia sceptical of subjecting the EU to supervision by the ECtHR.

Protests against how the ECtHR manages the dilemma between protecting human rights and respecting sovereignty came to a peak at a meeting of the Council of Europe's Committee of Ministers on the future of the European Court of Human Rights in Brighton 2012. The meeting inter alia agreed to subtle changes to the Convention. When Protocol 15 comes into force the Preface will conclude thus:

Affirming that the High Contracting Parties, in accordance with the principle

\footnotetext{
${ }^{1}$ This article was written under the auspices of ERC Advanced Grant 269841 MultiRights —on the Legitimacy of Multi-Level Human Rights Judiciary; and the Research Council of Norway through its Centres of Excellence Funding Scheme, project number 223274 - PluriCourts The Legitimacy of the International Judiciary. The present version has benefited from discussions at a conference on the Philosophical Foundations of Federalism University of Luxembourg May 5, 2014. I am grateful for comments received at that occasion and from Stian Øby Johansen.
}

Approximately as will appear in Philosophical Foundations of Federalism, Katja Stoppenbrink and Dietmar Heideman (eds.), 2016 de Gruyter . 
of subsidiarity, have the primary responsibility to secure the rights and freedoms defined in this Convention and the Protocols thereto, and that in doing so they enjoy a margin of appreciation, subject to the supervisory jurisdiction of the European Court of Human Rights established by this Convention. (Protocol No. 15 Amending the Convention on Fundamental Freedoms 2013)

This change introduces two new phrases into the Convention. The principle of subsidiarity is familiar from federal thought, expressing a rebuttable presumption to place authority as local as possible. The margin of appreciation doctrine was developed by the Court itself. The Court thereby grants a state the authority, within certain limits, to determine whether the rights of the ECHR are violated in a particular case.

Critics may fear that these two quite diffuse and contested phrases will further obfuscate rather than improve on the Court's response to the dilemma between human rights protection and respect for sovereignty. Subsidiarity is used in so many different ways that it may provide an intellectual guise to cover up the Court's complete abdication from the role of human rights protector in Europe by granting states broad discretion. EU accession - if it will indeed occur - will pose further challenges: does subsidiarity guide the decisions about which of the two European courts should be superior, and how they should exercise their authority? Should the EU enjoy a similar margin of appreciation as the member states of the Council of Europe? That might seem to follow from the general presumption in the treaty negotiations that the EU should be treated on an equal footing with the contracting states. For instance, the negotiation team behind the draft agreed inter alia that "current control mechanism of the Convention should, as far as possible, be preserved and applied to the EU in the same way as to other High Contracting Parties" (47+1 2013, para 7)

This chapter seeks to reduce such fears. The margin of appreciation, duly specified in ways guided by the principle of subsidiarity, can contribute to alleviate this tension in a defensible way. A 'Principle of Subsidiarity' can alleviate some of the challenges posed by the margin of appreciation doctrine, in particular that it sacrifices human rights protection on the altar of respect for state sovereignty. Section 1 presents the Margin of appreciation doctrine and some criticism raised against it, section 2 sketches versions of the principle of subsidiarity relevant for this discussion. Section 3 seeks to bring subsidiarity to bear on the question of which authority the ECtHR should enjoy within a multilevel European legal order, and in particular why it should grant states a certain margin of appreciation. Section 4 considers how these arguments concerning a margin of appreciation applies to the European Union - leaving the many other aspects of accession aside. 


\section{The margin of appreciation and its critics}

The margin of appreciation doctrine ('the Doctrine') is a practice whereby the Court sometimes defers to the state's own judiciary about whether the Convention rights have been violated. The Doctrine is often traced back to the 1958 Cyprus case where the then Commission asserted that the UK authorities "should be able to exercise a certain measure of discretion in assessing the extent strictly required by the exigencies of the situation" (Greece v United Kingdom 1958-1959). In this case the issue was a state of public emergency, an exemption clause in Art 15. A margin of appreciation is claimed by the Court to be appropriate for at least three main issue areas.

- 'Balancing' the rights against other urgent issues such as emergencies, public safety, the economic well-being of the country etc - as permitted for several rights to private life, religion, expression etc (Art. 8, 9, 10).

- 'Balancing' or 'trade-offs' among different private human rights in the Convention - such as between freedom of expression (Article 10) and privacy (Article 8)

- How to apply the norms to the specific circumstances of a state, which may depend on shared values and traditions or perceived threats.

To grant a margin of appreciation, the Court often requires that the accused state has undertaken a 'proportionality test' to check if the rights violation could have been avoided by other policies in pursuit of the same social objectives.

The Doctrine has received much praise and much criticism, some of both are well deserved. It expresses some respect for sovereign democratic self-government but only within some limits: for instance, the Court has hardly ever granted a margin of appreciation concerning infringements to rights to life, or against torture or slavery (Art 2, 3, 4). Yet the 'Doctrine' is so vague and multifarious that even to refer to it in the singular, and to call it a 'doctrine' seems unduly charitable. More fundamentally, the margin of appreciation doctrine may grant both the ECtHR and powerful states too much discretion, and put human rights at risk, contrary to the purpose of the ECHR.

There are at least three kinds of concern. Firstly, the Doctrine creates legal uncertainty, because states are unable to predict and hence cannot avoid violations of the ECHR (Lester 2009; cf Brauch 2005, 125; Macklem 2006; Arai-Takahashi 2013). Indeed, even the judges of the Court disagree about the Doctrine to such an extent that legal certainty seems at risk:

I believe that it is high time for the Court to banish that concept from its reasoning. It has already delayed too long in abandoning this hackneyed phrase and recanting the relativism it implies

(Z v Finland 1997, Judge De Meyer partly dissenting)

To some extent the uncertainty is due to the legal norms, rather than the margin of 
appreciation doctrine itself. Consider Art. 10 which protects freedom of expression but

subject to such formalities, conditions, restrictions or penalties as are prescribed by law and are necessary in a democratic society, in the interests of national security, territorial integrity or public safety, for the prevention of disorder or crime, for the protection of health or morals, for the protection of the reputation or rights of others, for preventing the disclosure of information received in confidence, or for maintaining the authority and impartiality of the judiciary. (Art 10, para 2)

The Court often - but not always - grants states a margin of appreciation in determining whether such interests override the right. Thus in the Sunday Times case, a majority of 11 judges found against the UK, that Art 10 protected newspapers reporting on a case. But nine dissenting judges held that this should have been left to the domestic judiciary:

The difference of opinion separating us from our colleagues concerns above all the necessity of the interference and the margin of appreciation which, in this connection, is to be allowed to the national authorities. (The Sunday Times $v$ United Kingdom 1979).

Similar disagreements among judges are legio (Observer and Guardian v United Kingdom 1991; Wingrove v United Kingdom 1996). One upshot of this criticism is that the Doctrine should be made more precise, and more consistently applied, than is presently the case.

A second concern is that the vague Doctrine leaves too much discretion to the judges. Again, it would seem that one main response is to make the rules of the doctrine - including the consensus test - more precise.

A more precise Doctrine does not automatically avoid other objections: that such discretion entails a failure of the ECtHR to protect human rights in the short and long run. The Court thereby "side-step[s] its responsibility as the ultimate interpretative authority in the Convention system" (Yourow 1996, 181). Indeed, "[t]he essence of the international control mechanism may evaporate if there is in fact no effective check upon national power" (ibid)

Is this a correct criticism? If the Court is in the habit of granting all states a very wide margin, the value added of the ECtHR diminishes: it leaves each state to be judge in its own case. Yet as practiced, the margin is not granted to the nonderogable rights to life (Art 2), against torture (Art 3), slavery or forced labour (Art 4), though the ECtHR has referred to the margin of appreciation with regard to some aspects of Art 2 (cf. Budayeva v Russia 2008) and Art 3 (M.C. v Bulgaria 2003, and Berganovic v Croatia 2009). ${ }^{2}$ Moreover, the margin of appreciation often concerns a 'balancing' among rights in the ECHR. Such 'balancing' does not entail less stringent human rights protection, but rather how the government gives some rights a certain

2 Thanks to Oddný Mjöll Arnardóttir for these references. 
weight compared to other rights. Finally, national courts enjoy such a margin only when the ECtHR is satisfied that the national court has duly considered several conditions, in the form of a proportionality test - in good faith (Rasmussen $v$ Denmark 1988).

So I submit that a more specified margin of appreciation can reduce several of the concerns stemming from vagueness, and not risk its objective unduly. But such specification must be guided by an understanding of why a margin of appreciation should be accepted at all. This is the question for which a Principle of Subsidiarity may be thought to offer guidance.

How can the Doctrine help prevent domination in the form of human rights abuses over citizens from their own domestic authorities, without subjecting wellfunctioning democracies to undue constraints from international judges at the Court, as part of the multi-level European legal order? I submit that one way to limit the risk of domination is to specify the doctrine, in light of a general account of what the ECtHR should do - and guided by principle of subsidiarity.

\section{Subsidiarity}

Several authors claim that a principle of subsidiary supports 'the' margin of appreciation doctrine (Benvenisti 1999, Spielmann 2012; Kratochvil 2011; del Moral 2006, 614; Sweeney 2005). I submit that there is some truth to this claim, mainly in that appeals to subsidiarity indicate the sorts of arguments that may be made.

The 'principle of subsidiarity' has a variety of versions, each with long historical roots ( Follesdal 1998). In the history of political thought principles of subsidiarity address the issue of how to allocate or use authority within a political or legal order, typically amongst a centre and member units within some sort of federal structure. For our purposes what unites the various traditions is the assumption that the burden of argument lies with attempts to centralize authority. Various principles of subsidiarity express a commitment to leave as much authority to the more local authorities as possible, consistent with achieving the stated objectives. Different versions will argue that member units or the centre should have the final say for such decisions; or that central action should be permitted or instead required under certain conditions; some versions hold that central action should replace local decisions, others maintain that the centre should rather seek to bolster the local authority's ability to make correct decisions.

For our purposes, it may be helpful to distinguish a 'state centric' principle of subsidiarity from 'person-centred' versions of the principle. The former matches a standard presumption of international law, that sovereign states are free to decide whether they have shared objectives which they judge are better secured by delegating some of their authority to some central body - such as an international court. Such arguments may be based on states' inability or unwillingness to achieve sufficient coordination absent some centralised body, or simply the need for mutual trust that each state actually do their share. Such pooling of sovereignty may thus 
differ across issue areas depending on the interests of states, the nature of their collective problem, and the new risks induced by a centralized authority.

From this perspective, the central puzzle of international human rights courts is: if they are the solution, what exactly is the problem states have? In light of the answer, what scope should a domestic court retain for adjudicating the state's compliance with the human rights treaty? One answer to the question is that a state may want to 'bind itself' or commit itself to a regional or international human rights court (Alter 2008). At least two audiences are important for states submitting themselves to the ECHR: they may thereby become more credible in the eyes of their citizens and thereby secure their more willing compliance. And such credibility in the eyes of other states is important for states who pool sovereignty - such as in the EU.

It might seem odd that scrutiny and risks of vocal criticism and sanctions by an international body may enhance trust. The answer lies in authorities' need for credibility among the governed. We can draw on Margaret Levi's discussions of trust to understand this connection. She holds firstly that citizens' sense of political obligation helps elicit compliance:

Empirically, political obligation rests on the citizen's perception that government actors and other citizens are trustworthy. The activation of obligation implies institutional arrangements that make promises and commitments credible, but it may also require extraordinary acts of compensation to overcome distrust based on past experiences." (Levi 1998, 208)

Second, an important component to secure such voluntary compliance with the law is general trust in the rule of law. Agents of the state must be trusted to use their powers for the common good, and be law abiding and law enforcing. Third, courts that are somewhat independent of the government can bolster such trust in several ways: both to maintain the rule of law, and to give citizens and officials reasons to believe that their rulers indeed uphold the rule of law.

The political leadership can express its commitment to the rule of law precisely by choosing to be monitored by independent courts:

What defines its commitment to the rule of law is the willingness to be bound by the laws and to ensure that the laws are implemented and enforced universally." (Levi and Epperly 2010, 6)

By deciding to be subject to courts, the leadership ties its own hands and ensures some transparency about what they do. A desired effect is to gain credibility among subjects, by subjecting themselves to such scrutiny. Governing bodies thereby enhance citizens' trust that the authorities do indeed seek to respect and promote the best interests of the subjects. External actors in the form of independent international tribunals thus provide assurance to citizens and other authorities about the authorities' use of power and commitment to the rule of law.

Generally, one may think that a state-centred version of subsidiarity would 
support as broad a margin of appreciation as possible, consistent with these objectives of maintaining trust, so that the state retains maximal authority.

A 'person-centred' version of subsidiarity does not give such primacy to the state and the interests of states, but instead insists that subsidiarity goes 'all the way down.' The states are not the 'natural' reservoir of sovereign authority, but should only have such legal powers and immunities as needed to secure the shared interests of its members: the communities and municipalities - and ultimately the citizens whose states they are.

From this point of view, the important design challenge of international human rights courts and the margin of appreciation is to grant the state enough authority to promote the interests of its citizens and of foreigners, whilst preventing the abuse of such powers in the form of human rights violations - and generate trust that this is the case, when such trust is well deserved. Regional or international human rights courts can provide such protections - but at the same time, citizens run the risk that these courts misuse or even abuse their power from incompetence or ill will. In particular, the courts should not limit democratic self-governance unduly, insofar as such governments are sufficiently responsive to the best interests of their citizens.

For our purposes here, I submit that the 'person centric' principle of subsidiarity is more plausible. Such conceptions of subsidiarity will not support a broad margin of appreciation in general: that would indeed be contrary to the objectives of the ECHR (Kratochvil 2011, 332). Instead, the arguments for the Doctrine must show that certain interests of individuals require centralized authority above the state, e.g. human rights protected and promoted by the ECHR, but that a margin of appreciation is still permitted or even required.

Indeed, why should a person-centred principle of subsidiarity allow a margin of appreciation at all? It would seem to re-create the problems for which the ECtHR were the solution, namely to prevent the state from being judge in its own case - be it human rights violations or arbitration disputes. States use human rights treaties to bind themselves. Compare the treaties which primarily to solve shared problems among states, where each state only binds itself as much as necessary to obtain those benefits. In contrast, a state binds itself to an international human rights court in order to enhance its own credibility as a "rule of law", human rights respecting political system. One implication is that treaty interpretations and adjudication should not minimize the curtailment of state sovereignty. Nor should a margin of appreciation be as broad as possible - to the contrary, why should states enjoy any margin? We now turn to consider why individuals' interests may require that international human rights judicial review be constrained by a margin of appreciation. This requires us to look at the ECtHR as part of a multi-level legal order.

\section{Applying the Principle of Subsidiarity to the ECtHR and its}




\section{Margin of Appreciation}

To apply the principle of subsidiarity properly to the margin of appreciation doctrine involves several steps. We start with the objectives and other functions of the ECHR.

These objectives, stated in the Preamble, are, in short, to help secure "the universal and effective recognition and observance of the Rights therein declared" and "to take the first steps for the collective enforcement of certain of the rights stated in the Universal Declaration." Note that this objective does not require harmonization across states, but rather to ensure certain thresholds of human rights protection. The abstraction of human rights may be amongst their virtues, since they can be specified in different ways to reflect such differing circumstances (Etinson 2013). Variation among institutions in different jurisdictions is thus not a threat to this objective - unlike treaties which explicitly aim at the harmonization of various rules, such as the EU.

Another important de facto function of the ECtHR concerns its role in the European Union. As per the Copenhagen Criteria it a gate keeper for entry, in that all applicant states must become subject to the Court as members of the Council of Europe. Moreover, the Court contributes to monitor whether existing member states respect human rights. The latter is important not only for the citizens within the country being monitored, but arguably directly relevant for all in the EU. The Lisbon treaty allows secondary law making in many issue areas on the basis of complex qualified majority voting (European Council 2007, Art 16.3-4). Thus inhabitants are subject to decisions largely decided by politicians of other states than their own. They have good reason to insist that those politicians must be strongly committed to human rights, if the subjects are to be able to trust the good will and competence of their new rulers. Suspected violations of human rights triggered reactions against Austria after elections there in 2000 (Follesdal 2006; Follesdal 2007). That experience led to the inclusion of a more cautious procedure for the EU in the Treaty on European Union (Treaty on European Union, Nice Amendments 2001, Art 7.1).

The next question is why, according to a person-centred principle of subsidiarity, should these objectives require the centralization of adjudication of human rights violations to a regional court at all? And which powers should it have - given that full harmonization is not an objective? The express role of the ECtHR is to assist states in securing these objectives: to "ensure the observance of the engagements undertaken by the High Contracting Parties" (Art 19 ECHR). The ECtHR is thus not authorised to promote and protect human rights by all means. Rather, the task of the ECtHR is 'subsidiary' or supportive and supplementary vis-avis the states, to supplement and strengthen the protection offered by domestic judiciary. States remain primary protectors of human rights. The state remains the primary responsible actor to respect human rights.

Note that to ascertain compliance with the convention requires local and counterfactual knowledge about avoidable abuse or neglect by means of the laws and policies of their government, familiarity about the local culture and 
circumstances, the risks individuals face due to complex interplay between majority culture and institutions - and about a range of feasible alternative policies which may avoid such violations. This is one reason why the chamber of the ECtHR which hears a case always includes the judge with respect to that particular country.

As regards the need for human rights assurances in a federation with qualified majority voting, international supervisory bodies seem necessary to protect citizens against other EU member state governments, who now share decision making authority over them. This role of human rights judicial review may become more important as the EU becomes more subject to majoritarian mechanisms where all member states can vote. It is then especially important that citizens can trust that all member state authorities exercise such powers responsibly. No political party should enjoy domestic political power that may lead them to favour EU policies that violate human rights. Human rights courts can give assurance to citizens and other member state governments that each of the state governments is committed to human rights, and that majority rule among them thus is not overly risky. Such concerns are arguably even more salient insofar as EU authorities undermine the democratic bases of legitimation in the member states (Follesdal and Hix 2006).

The next question is then, given the multi-level system where the ECtHR plays this supportive, supplementary role: what contribution does a margin of appreciation doctrine provide? It essentially returns adjudication of the ECHR to the domestic courts of the very same member state accused of a violation.

From the perspective of a person-centred conception of subsidiarity, the state organs should retain the final authority to determine compliance with the Convention when the ECtHR cannot or is unlikely to provide extra protection. That is: a margin of appreciation should apply insofar and for those objectives, and under those conditions, where the domestic courts and other authorities are at least as well suited as the ECtHR to determine whether there is a breach. For instance, there should be a very low risk that the domestic court will skew its judgment unduly in favour of the state in its dispute with its citizens.

What arguments of this kind may be offered for the margin of appreciation doctrine?

Firstly, recall that the Court holds that the margin of appreciation is restricted in the rights it applies to. The Court hardly grants any margin of appreciation when certain rights are at risk under certain emergencies, regardless of what states claim, namely rights against torture or slavery.

Secondly, in the three main issue areas where the Court holds that domestic authorities are better placed than the ECtHR to judge due to local knowledge, this assessment seems plausible: balancing rights against certain urgent issues, balancing among rights, and applying the norms to specific circumstances where there are local traditions and culture at stake. The Court often claims that domestic authorities are in principle better placed than an international court to evaluate such local needs and conditions (Hatton $v$ the United Kingdom 2003, 634). Thus the margin of appreciation may be interpreted and assessed as a way the Court expresses subsidiarity by giving 
the domestic judiciaries the benefit of any doubt. However, the person-centred conception of subsidiarity does not warrant such a general presumption. The Court must assess the risk of human rights abuses in a more nuanced way, as indeed it does.

The ability of local authorities to strike the balance right is not enough: Under which circumstances are local authorities likely to make decisions in ways that respect human rights appropriately? When, in short, will domestic laws and policies be sufficiently responsive to the best interests of all citizens, and when will the domestic authorities have mechanisms of self-correction in this regard? I submit that this is more likely under conditions of democratic rule under the rule of law. Such polities are likely to be more responsive to human rights and self-correcting than alternative modes of governance. Under functioning democratic mechanisms and the rule of law the population deliberates about alternative policies and legislative proposals in light of their implications for all affected parties, so as to promote broadly shared interests whilst avoiding harm to anyone; and an independent judiciary protects the human rights of the inhabitants.

On this line of reasoning, the ECtHR is unlikely to provide a better assessment of violations of the Convention than domestic judiciaries when the sort of deliberation has occurred in good faith. Insofar as this argument holds, the ECtHR should allow no margin of appreciation for rights concerning political participation, freedom of expression and other rights required for well-functioning democratic decision making. And indeed, this appears to be a pattern of the margin of appreciation practice:

taking into account the vital importance in a democratic society of freedom of expression and freedom of the press, the State's margin of appreciation in these cases is very narrow indeed. (Observer and Guardian v United Kingdom 1991, partly dissenting opinion of Judge Pekkanen; and cf. Handyside v United Kingdom 1976, para 49)

Furthermore, the majoritarian democratic mechanisms are not particularly reliable in securing the vital interests and equal respect for those who are likely to regularly find themselves outvoted. For this reason, ICs should not grant a wide margin of appreciation for the vulnerable interests of minorities - such as freedom of religion, even in well-functioning democracies. Again, this pattern appears to be in accordance with the current practice of the margin of appreciation doctrine.

Finally, even democratic deliberative majoritarian decision making is not always well functioning. While domestic authorities may know more about the domestic setting, they need not know much about which alternative policies may serve the legitimate interests and values sufficiently well. This requires comparative perspectives which domestic authorities may be too myopic to discern. Thus it makes sense for the Court to check whether the state has performed a proportionality test when certain human rights appear to be at stake. Such a test checks that state authorities have not overlooked less invasive alternatives, and have not ignored the 
impact on some groups - and at the same time ensure that the population can be ascertained that this is fact the case. Such deliberation about alternatives and their impact is of course what well-functioning democratic decision making should be based on.

Insofar as such proportionality testing has not occurred, in well-functioning democracies and elsewhere, the presumption in favour of domestic democratic decision making no longer stands. Indeed, the ECtHR hesitates to grant a margin of appreciation unless there is evidence that the domestic authorities have undertaken such a proportionality test. Thus the Court often states that

from Hirst v. the United Kingdom (no. 2) it could be deduced that the margin of appreciation would be narrower when Parliament had not analysed and carefully weighed the competing interests or assessed the proportionality of blanket rules. (Lindholm and Others v. Norway [Tomtefestesaken] 2012, 85)

I submit that such statements by the Court may nudge states into more careful proportionality testing. The Court thereby performs its subsidiarity, supportive function, helping to improve the domestic democratic processes.

\section{Should the European Union enjoy a margin of appreciation?}

If the EU does become party to the ECHR, this will be an important challenge both for the EU and for the ECtHR. Ratification may reduce the substantive and institutional fragmentation of international human rights law in Europe. But conflicts will not disappear without trace.

One may wonder what value is added if the EU should accede to the ECHR. At first glance not much seems to be at stake, since all member states of the EU have already ratified the ECHR and are subject to review by the ECtHR. The EU - and hence the Union organs including the CJEU - are already treaty bound to respect the ECHR, and the Lisbon Treaty enhances the legal standing of the EU Charter on Fundamental Rights.

One important change wrought by EU's accession is that the EU will be subject to the judgments of the European Court of Human Rights (ECtHR). This court will also monitor, adjudicate and sanction any violations that might arise. They may be violations which the CJEU overlooks - and potential violations by the CJEU itself. ${ }^{3}$ Such monitoring may achieve several benefits. Firstly, it helps reduce the risk of violations of the ECHR - violations that the CJEU might not have identified. Such protection is especially important insofar as the chains of delegation from national authorities to EU institutions is too long, and even more so when important EU bodies such as the European Central Bank and the European Commission explicitly or de facto operates beyond direct democratic control. Their treatment both of Union citizens and of their own employees will be held more closely to human rights standards both by the Charter and by ratification.

Human rights bodies may be especially important institutional mechanisms in

\footnotetext{
${ }^{3}$ I am grateful to Stian Øby Johansen for this reminder.
} 
the EU due to the pervasive mistrust characteristic of 'coming together' federations in general(Stepan 2000). Such political orders emerge when governments seek objectives beyond the reach of any single state, and that cannot be secured by treaty agreements alone. Examples of such objectives include external defense, or common regulations in response to a globalizing economy. A crucial concern for the joining states is to ensure such shared objectives without allowing undesired centralization or harmonization, or other abuse of central authorities. Human rights regulations and monitoring that apply to the centre of the federation reduce or remove some such fear.

This review mechanism can also provide much needed trust that the EU does indeed respect these constraints. Such human rights review can serve as a valuable trust-building feature among citizens and authorities in an exceedingly complex multi-level political structure. This is of particular value in a political order where individuals have several sometimes conflicting political obligations, toward both their national and European legislation, and where such conflicts may give rise to understandable suspicions among other Union citizens and politicians. In the case of the EU, the national and Union authorities may thus want the domestic populations and national constitutional courts to trust their human rights compliance. By ratifying the ECHR the national authorities give evidence of such sincerity, since they thereby let independent international organs monitor and even sanction Union authorities.

These benefits notwithstanding, we can expect conflicts of interpretation between the ECtHR and the CJEU, and both about the EU's Charter of fundamental rights relationship to the ECHR and about interpretations of the ECHR. While our focus here is on whether the EU should enjoy a margin of appreciation, the arguments require a brief historical backdrop.

The 1999 Cologne European Council decided to consolidate the fundamental rights that applied to the EU level and make them more visible in a Charter of Fundamental Rights (European Council 1999, Art. 44 and Appendix IV) (Heinz 2006). The Charter provided a much needed clarification of the legal human rights obligations of member states, and received full legal effect, after prolonged discussions, when the Treaty of Lisbon entered into force December 1, 2009.

The Charter includes a wide range of legal rights. It lists a range of civil, political, economic and social rights of European citizens and others resident in the EU. These legal rights are said to draw on the ECHR, and the case law of the ECtHR, as well as rights derived from the "constitutional traditions" common to the Member States; economic and social rights within the European Social Charter and the Community Charter of Fundamental Social Rights of Workers; and other international conventions to which the EU or its Member States are parties. However, the European Council made no explicit mention of any UN declarations or conventions, though they might be thought to express rights derived from the common 'constitutional traditions'.

Article 52(3) of the Charter seeks to alleviate any conflicts between it and the 
ECHR by insisting that where there are conflicts, "the meaning and scope of those rights shall be the same as those laid down by the said Convention." This presumably means that the judgments of the ECtHR will be binding on the CJEU. Hitherto the CJEU has seemed to accept the ECtHR's view that member states cannot avoid their obligations under ECHR even as members of the EU, and the CJEU has so far seemed to aim for consistency. But whose interpretation will be decisive is a matter that remains to be discovered - and this may become a contested issue. Indeed, one of the several objections the CJEU raised in its opinion concerning the draft ratification treaty was precisely this. ${ }^{4}$

Following accession the ECHR will become part of EU law (European Union 2007, Art 216(2)). This threatens the role of the CJEU as the ultimate authority on interpretation of EU law - unless the ECtHR always respects the CJEU's decisions. In particular, the ECtHR should not be able to bind the EU to the ECtHR's interpretation of the ECHR (CJEU 2014, para 183-4). The CJEU claimed that no member state should be allowed to maintain 'higher' human rights standards than the Charter where the EU has harmonized the relevant laws (Melloni ). Thus the CJEU asserts that its interpretation of the ECHR - presumably interpreting it consistently with the Charter - should be authoritative, rather than deferring to the ECtHR's interpretation. ECHR organs should not bind the EU to a particular interpretation of rules of EU law. The point of ratification of the ECHR would however seem to be precisely to subject the EU to the independent control by the ECtHR, on the basis of its interpretation of the ECHR. A reservation to this effect by a state acceding to the ECHR would presumably be struck down as incompatible with the object and purpose of the treaty. ${ }^{5}$

May such differences of interpretation occur in practice? One important source of discrepancy is that the CJEU must weigh the various values and objectives of the EU against each other. While human rights are included among the Union's values in Article 2, Article 3 states several objectives of the Union. In particular, the four economic freedoms of the single market - the free movement of people, goods, services and capital - are on the same legal footing as the Charter of Fundamental Rights. Several cases indicate how the CJEU seeks to 'balance' human rights against these market enhancing freedoms when they conflict, e.g. by means of a proportionality test (Vries 2013, discussing inter alia Laval 2007, Schmidberger 2003, Viking 2007, Omega 2004). ${ }^{6}$ If the EU accedes to the ECHR on the ordinary terms, it will be for the ECtHR to decide when it is asked to judge the CJEU's weighing. Consider in particular that the ECtHR, but not necessarily the CJEU, grants human

\footnotetext{
${ }^{4}$ The opinion states several other objections. The opinion has received much attention, including at http://eulawanalysis.blogspot.com.br/2014/12/the-cjeu-and-eus-accession-to-echr.html , http://blogg.uio.no/jus/smr/multirights/content/opinion-213-a-bag-of-coal-from-the-cjeu , http://www.verfassungsblog.de/opinion-213-eu-accession-echr-christmas-bombshell-european-courtjustice/\#.VbD-VbPtmkp, http://echrblog.blogspot.com.br/2014/12/cjeu-rules-draft-agreement-on-eu.html , http://europeanlawblog.eu/?p=2731

${ }^{5}$ http://europeanlawblog.eu/?p=2731\#sthash.Md1Swv9M.dpuf

${ }^{6} \mathrm{I}$ am grateful to Stian Øby Johansen for nudging this expansion.
} 
rights priority over ordinary legislation and public policies.

On the other hand, the ECtHR grants a certain scope of discretion to the parties who have ratified the ECHR. Should the EU and the CJEU come to enjoy similar leeway?

Recall that the "Margin of Appreciation" is defended as a way to respect domestic democratic processes that are more attuned to local peculiarities and traditions, when the policies and legislation has been subject to a proper proportionality test by the authorities:

By reason of their direct and continuous contact with the vital forces of their countries, State authorities are in principle in a better position than the international judge to give an opinion on the exact content of these requirements [of morals] as well as on the 'necessity' of a 'restriction' or 'penalty' intended to meet them. (Handyside 1976, para 48).

However, this justification does not hold for the EU bodies (Follesdal and Hix 2006; Follesdal 2014). The EU is widely criticized for being out of touch with local circumstances, and the democratic pedigree of EU decisions is contested. At best, the chains of delegation are too long. Furthermore, the legislative process is not clearly set up to provide the requisite proportionality test.

Some observers claim that the ECtHR uses the margin of appreciation as a 'double standard', e.g. to avoid conflicts with more powerful states (Benvenisti 1999, 844). If so we may suspect that present - and future - 'harmony' with the CJEU simply reflect the power of the latter rather than a normatively defensible respect for the democratic processes behind EU rules. In defense, these flaws in the democratic quality of the EU may change - indeed, the ECtHR might nudge the EU toward a more satisfactory proportionality test, if the EU accedes to the ECHR. Furthermore, I submit that the ECtHR may contribute in many such ways to render rules, citizens and authorities more trustworthy. Assurance that European decisions will not threaten individuals' human rights, and that the national authorities who participate in joint decision making respect human rights domestically, may thus increase the likelihood that citizens and national authorities will accept the majoritarian decisions of the EU (Binder 1995; Weiler 1991).

If the complex EU order is to deserve compliance and support by its citizens and member states, it must have well developed policies to monitor and protect against suspected human rights violations committed by Union bodies. Such policies must also be trustworthy. The ECtHR may therefore play an especially valuable role in providing assurance that EU authorities actually comply with the ECHR. Note that also when EU authorities actually act within their mandate, they may benefit from such independent monitoring: Such monitoring helps assure citizens that the authorities do indeed act within their mandate.

Sceptics may still wonder how the ECtHR contributes to trust, given that it regularly finds states in violation of the ECHR. If this were indeed a correct description, the objection is correct: then, the ECtHR does not persuade citizens to 
support the EU - or their member states. Human rights norms and bodies will only contribute to assurance in these ways if in fact the institutions satisfy such human rights norms. Otherwise the focus on human rights will instead serve to bring even more attention to these failures - and lead to less compliance or at least greater discussion about whether to comply. I submit that it is precisely this risk that renders the ECtHR a trustworthy trust-building mechanism, which the member states - and the EU - can use strategically: The governments 'up the ante' by subjecting its own state and the EU to such review, and thus show that they are sincerely committed to enhance the human rights of its inhabitants. When the states or the EU does in fact generally comply with the ECHR, as assessed by the ECtHR, this monitoring does provide assurance that the state - and EU - authorities merit obedience.

\section{Conclusion, criticisms reconsidered}

In the debate about whether the margin of appreciation doctrine amounts to an abdication by the Court, the present arguments have come to the rescue of the Doctrine. With the features laid out here, applied within these scope conditions, the Doctrine seems compatible with and even required by the rationale for placing some authority with the ECtHR to adjudicate human rights - when this supplements review by domestic courts. When constrained in this way, a margin of appreciation doctrine serves the particular objectives of the ECtHR within the multi-level European legal order, including its role in monitoring human rights compliance by member states in the European Union. Note, however, that it is not obvious that similar features and scope conditions should be part of a 'margin of appreciation doctrine' for other international courts, with different relations to other actors in the multi-level global system, and with other objectives with different normative weight than human rights. Nor is it clear that the ECtHR should grant the EU such a margin, if the EU becomes subject to the ECHR. The margin of appreciation doctrine was originally meant to accommodate the legitimate diversity among national legislations and traditions due to local circumstances, and to defer to their familiarity concerning the local needs - as long as they perform a proportionality test. It remains an open question whether similar arguments count in favour of granting the EU discretion in how it chooses to respect and promote human rights, since it can hardly be said to have a 'national' tradition of its own, nor are Union authorities obviously 'closer' to or more sensitive to local circumstances than the ECtHR. To the contrary, the EU may be suspected of being insufficiently sensitive to human rights concerns relative to the other objectives and values laid down in the Lisbon Treaty.

Consider in conclusion, the criticisms voiced against the margin of appreciation doctrine and how a person-centred conception of subsidiarity can alleviate them. The defence presented here should not cast doubt that the current margin of appreciation doctrine of the ECtHR is vague and partially inconsistent. The implication is that the Doctrine should be improved, rather than be abolished. These arguments thus support the change to the Preamble of the ECHR wrought by 
Protocol 15. But the general and vague appeal to 'subsidiarity' will neither help settle the dilemmas between sovereignty and human rights protection, nor provide much guide to the Court's use of the margin of appreciation in the cases brought before it. We may hope that Protocol 15 and the possible accession of the EU to the ECHR will fuel more philosophically informed attention to the Court's interpretation of subsidiarity and its margin of appreciation doctrine, by philosophers, lawyers and political scientists alike. Indeed, we may hope that the Court draws on a well reasoned conception of subsidiarity to further develop its Doctrine. The Doctrine should be specified not in the light of a state centric conception of subsidiarity which would tend to grant all states a wide margin to be judge in their own case as long as other states would not stop cooperation with them. Rather, a person-centred subsidiarity principle should be a guide. It already supports several of the features of the current Doctrine. They must be further elaborated, so that the margin of appreciation doctrine becomes worthy of that name, and so that the member states of the Council of Europe, and the European Union become and remain worthy of their citizens' obedience.

\section{References}

47+1 2013. 'Draft Explanatory Report to the Agreement on the Accession of the European Union to the Convention for the Protection of Human Rights and Fundamental Freedoms - Appendix V.' Fifth Negotion meeting between the CDDH ad hoc negotiation group and the European Commission on the Accession of the European Union to the European Convention on Human Rights, Final report to the CDDH 47+1(2013)008rev2

Alter, Karen 2008. 'Delegating to International Courts: Self-Binding vs. Other-Binding Delegation.' Law and contemporary problems 71: 37-76.

Arai-Takahashi, Yutaka 2013. "The Margin of Appreciation Doctrine: A Theoretical Analysis of Strasbourg's Variable Geometry." In The European Court of Human Rights, edited by Andreas Follesdal, Birgit Peters and Geir Ulfstein, 62-105. Cambridge: Cambridge University Press.

Benvenisti, Eyal 1999. 'Margin of Appreciation, Consensus, and Universal Standards.' International law and politics 31: 843-54.

Binder, Darcy S. 1995. 'The European Court of Justice and the Protection of Fundamental Rights in the European Community: New Developments and Future Possibilities in Expanding Fundamental Rights Review to Member State Action.' Jean Monnet Working Papers 1995, no. 4.

Brauch, Jeffrey. A. 2005. 'The Margin of Appreciation and the Jurisprudence of the European Court of Human Rights: Threat to the Rule of Law.' Columbia Journal of European Law 11: 113-50.

CJEU, Court of Justice of the European Union 2014. 'Opinion Pursuant to Article 218(11) Tfeu - Draft International Agreement - Accession of the European Union to the European Convention for the Protection of Human Rights and 
Fundamental Freedoms - Compatibility of the Draft Agreement with the EU and Feu Treaties.' Curia.europa.eu, no. 2/13.

del Moral, Ignacio de la Rasilla 2006. 'The Increasingly Marginal Appreciation of the Margin-of-Appreciation Doctrine.' German Law Journal 7, no. 6: 611-.

Etinson, Adam 2013. 'Human Rights, Claimability and the Uses of Abstraction.'

Utilitas 25: 1-24.

European Council 1993. 'Presidency Conclusions - Copenhagen Meeting.' SN 180/1/93.

- - - 2007. 'Treaty of Lisbon Amending the Treaty on European Union and the Treaty Establishing the European Community, Signed at Lisbon, 13 December 2007.' Official Journal of the European Union 50, no. 2007/C 306/01.

European Union 2007. 'Treaty on the Functioning of the European Union.' Official Journal C $326,26 / 10 / 2012$ P. $0001-0390$.

Follesdal, Andreas 2014. "Democratic Standards in an Asymmetric Union." In Democratic Politics in a European Union under Stress, edited by Olaf Cramme and Sara B. Hobolt, 199 -216. Oxford: Oxford University Press.

- - - 2006. "Justice, Stability and Toleration in a Federation of Well-Ordered Peoples." In Rawls's Law of Peoples: A Realistic Utopia?, edited by Rex Martin and David Reidy, 299-317. Oxford: Blackwell.

- - - 1998. 'Subsidiarity.' Journal of Political Philosophy 6, no. 2: 231-59.

- - - 2007. 'Toward Self-Sustaining Stability? How the Constitutional Treaty Would Enhance Forms of Institutional and National Balance.' Regional and federal studies 17, no. 3: 353-74.

Follesdal, Andreas, and Simon Hix 2006. 'Why There Is a Democratic Deficit in the EU: A Response to Majone and Moravcsik.' Journal of Common Market Studies 44, no. 3: 533-62.

Handyside v United Kingdom, App no 5493/72 European Court of Human Rights (1976) EHRR 24523.

Hatton $v$ the United Kingdom, ECtHR (2003) 611.

Heinz, Wolfgang 2006. "The EU External Relations and Human Rights." In Human Rights in Europe. A Fragmented Regime?, edited by Malte Brosig, 184-207.

Frankfurt: Peter Lang.

International Transport Workers' Federation v Viking, ECJ (2007) ECR Case C-438/05 I10779.

Kratochvil, Jan 2011. 'The Inflation of the Margin of Appreciation by the European Court of Human Rights.' Netherlands Quarterly of Human Rights 29, no. 3: 32457.

Laval Un Partneri Ltd v Svenska Byggnadsarbetareförbundet, ECJ (2007) ECR Case C341/05 I-11767.

Lester 2009. 'The European Court of Human Rights after 50 Years.' European Human Rights Law Review 4: 461-78.

Lindholm and Others v. Norway [Tomtefestesaken], App no 13221/08 ECtHR (2012) Series B 13221/08. 
Macklem, Patrick 2006. 'Militant Democracy, Legal Pluralism, and the Paradox of Self-Determination.' International journal of constitutional law 4: 488-516.

Melloni, App no C-399/11 CJEU (2013).

Observer and Guardian v United Kingdom, App no 13585/88 ECtHR (1991).

Omega Spielhallen- Und Automatenaufstellungs- Gmbh v Oberbürgermeisterin Des Bundesstadt Bonn, ECJ (2004) ECR Case C-36/02 I-9609.

Council of Europe. Protocol No. 15 Amending the Convention on Fundamental Freedoms.

Rasmussen v Denmark, ECtHR (1988) Ser B 71.

Schmidberger, Internationale Transporte Und Planzüge v Republik Österreich., ECJ (2003) ECR Case C-112/00 I-5659.

Spielmann, Dean 2012. 'Allowing the Right Margin. The European Court of Human Rights and the National Margin of Appreciation Doctrine: Waiver or Subsidiarity of European Review?' Cambridge Yearbook of European Legal Studies 14.

The Sunday Times $v$ United Kingdom, ECtHR (1979).

Sweeney, J 2005. 'Margins of Appreciation: Cultural Relativity and the European

Court of Human Rights in the Post-Cold War Era.' International and

Comparative Law Quarterly 54, no. 2: 471--.

Treaty on European Union, Nice Amendments 2001. Official Journal of the European Communities.

Vries, de 2013. 'Balancing Fundamental Rights with Economic Freedoms According to the European Court of Justice.' Utrecht Law Review 9, no. 1.

Weiler, J. H. H. 1991. 'The Transformation of Europe.' Yale Law Review 100: 1-81.

Wingrove v United Kingdom, App no 19/1995/525/611 (1996).

Yourow, Howard Charles 1996. The Margin of Appreciation Doctrine in the Dynamics of European Human Rights Jurisprudence: Brill.

Z v Finland, App no 22009/93 ECtHR (1997) European Human Rights Reporter 25371. 